\title{
Marital Status Code
}

National Cancer Institute

\section{Source}

National Cancer Institute. Marital Status Code. NCI Thesaurus. Code C93592.

A coded value specifying a domestic partnership status. 